\title{
The Accounting Reform in Russia. How to Teach Economists?
}

\author{
Irina Prosvirina $\square$ \\ Doctor of Sciences in Economics \\ $\underline{\text { ORCID }}$ \\ E-mail: irina.prosvirina@susu.ru \\ Department Head, School of Economics and Management, South Ural State University (National Research University), \\ Chelyabinsk, Russia
}

\author{
Aleksey Ivanov \\ Associate Professor, Candidate of Sciences in Economics \\ ORCID \\ E-mail: ivanov.chel@list.ru \\ School of Economics and Management, South Ural State University (National Research University), Chelyabinsk, Russia

\section{Leonid Zaionchik} \\ Associate Professor, Candidate of Sciences in Economics \\ $\underline{\text { ORCID }}$ \\ E-mail: zll1257@mail.ru \\ School of Economics and Management, South Ural State University (National Research University), Chelyabinsk, Russia
}

Journal of Corporate Finance Research, Vol. 15, No. 2, pp. 55-65 (2021)

For citation: Prosvirina, I., Ivanov, A. and Zaionchik, L. Z. (2021) “The Accounting Reform in Russia. How to Teach Economists?”, Journal of Corporate Finance Research | ISSN: 2073-0438, 15(2), pp. 55-65. doi: 10.17323/j.jcfr.20730438.15.2.2021.55-65.

Received 15 January 2021 | Peer-reviewed 23 January 2021 | Accepted 24 January 2021 


\section{Abstract}

Today, a major reform of national accounting standards is being conducted in Russia in order to harmonize the national system with IFRS. Employers require graduates to have the knowledge and ability to apply not only existing standards but also standards that will be introduced in the coming years as well as international standards. This creates a unique challenge for universities that have to teach students three accounting systems at the same time. This has required changing existing teaching methods. The present study is based on the experience of South Ural State University. Since 2016, it has introduced an intensive methodology for teaching bachelor's students in economics majoring in "Accounting, Analysis and Audit". The methodology promotes student research and analytical work. Students take research courses for 5-7 semesters. In addition to assimilating academic disciplines, they analyse a large volume of materials published by the developers of the new standards. The task of this analysis is to draft sample federal accounting standards. In 2016-2020, over 120 students $(78 \%$ of all students enrolled in the programme) took part in this work. This has resulted in the preparation of specialists who are able to tackle accounting tasks in real companies. The methodology is applicable in all university departments offering bachelor's programmes in accounting.

Key words: accounting, accounting education, accounting reform, Russia, bachelor's programme, teaching methods 


\section{Introduction}

\section{Accounting reform in Russia}

Russia belongs to a group of countries making a gradual transition to IFRS while maintaining national accounting standards harmonized with international norms. A similar situation exists in most parts of the world. Thus, according to the IFRS Foundation ${ }^{1}, 144$ out of 166 countries represented in a 2018 study require the use of IFRS standards by all or most publicly traded companies. However, only 36 of these countries require IFRS for all companies. In particular, IFRS standards are directly used in Kazakhstan. In such conditions, fewer difficulties seem to arise. However, most countries have adopted combinations of IFRS and national standards. For example, listed companies in the Baltic states and the Czech Republic must apply IFRS standards. Several countries allow the use of IFRS instead of national standards. Among post-socialist countries, Hungary applies such a procedure. There are also countries whose national accounting standards are close to IFRS (e.g., Russia $)^{2}$. Thus, in most post-socialist countries, accounting standards are based simultaneously on two accounting systems.

In such conditions, students should acquire knowledge and skills in two accounting systems simultaneously: national standards and international standards.

\section{New national accounting standards programme}

A programme for the development of Federal Accounting Standards (FAS) over the subsequent three calendar years is adopted annually. The latest version was approved for the period 2019-2023 (Table 1).

Table 1. Federal Accounting Standards to be adopted in Russia in 2019-2023

\begin{tabular}{lll} 
FAS & $\begin{array}{l}\text { Estimated year } \\
\text { of compulsory } \\
\text { application }\end{array}$ & Developer \\
\hline $\begin{array}{l}\text { Inventories } \\
\text { Intangible }\end{array}$ & 2021 & AMC Foundation ${ }^{3}$ \\
Assets & 2022 & AMC Foundation \\
\hdashline $\begin{array}{l}\text { Lease Ac- } \\
\text { counting }\end{array}$ & 2022 & $\begin{array}{l}\text { Russian Ministry of } \\
\text { Finance }\end{array}$
\end{tabular}

\begin{tabular}{|c|c|c|}
\hline FAS & $\begin{array}{l}\text { Estimated year } \\
\text { of compulsory } \\
\text { application }\end{array}$ & Developer \\
\hline Fixed Assets & 2022 & AMC Foundation \\
\hline $\begin{array}{l}\text { Capital In- } \\
\text { vestments }\end{array}$ & 2022 & AMC Foundation \\
\hline $\begin{array}{l}\text { Documents } \\
\text { and Docu- } \\
\text { ment Flow in } \\
\text { Accounting }\end{array}$ & 2022 & $\begin{array}{l}\text { Russian Ministry of } \\
\text { Finance }\end{array}$ \\
\hline $\begin{array}{l}\text { Accounting } \\
\text { Reports }\end{array}$ & 2022 & $\begin{array}{l}\text { Russian Ministry of } \\
\text { Finance }\end{array}$ \\
\hline $\begin{array}{l}\text { Non-Profit } \\
\text { Activities }\end{array}$ & 2022 & AMC Foundation \\
\hline Income & 2022 & IPAR NPO ${ }^{5}$ \\
\hline $\begin{array}{l}\text { Financial } \\
\text { Instruments }\end{array}$ & 2022 & AMC Foundation \\
\hline $\begin{array}{l}\text { Membership } \\
\text { in Related } \\
\text { Entities and } \\
\text { Joint Ven- } \\
\text { tures }\end{array}$ & 2022 & $\begin{array}{l}\text { Russian Ministry of } \\
\text { Finance }\end{array}$ \\
\hline Expenses & 2023 & IPAR NPO \\
\hline
\end{tabular}

In 2018, the Russian Ministry of Finance recommended the approval of three new-generation standards developed by the AMC Foundation: "Inventories", "Fixed Assets" and "Capital Investments". These standards differ significantly from current accounting regulations. The draft standard "Inventories" has the following novel features:

- Inclusion of work-in-progress inventories in inventories

- Accounting for inventories purchased in instalments at a discounted value;

- Incorporation of the estimated liability for dismantling and disposal of inventories and environmental recovery of the land plot occupied by them into the cost of inventories;

- Ban on the inclusion of management expenses in the cost of inventories;

- Partial write-off of a semi-fixed part of general production costs for period expenses in case of a significant decline of production.

\footnotetext{
${ }^{1}$ Yurieva, Y. IFRS Standards. URL: https://www.fd.ru/articles/159206-standarty-msfo (in Russian; accessed 18 January 2021).

${ }^{2}$ Countries using or planning to adopt IFRS. URL: https://gaap.ru/articles/strany_uzhe_ispolzuyushchiesya_msfo_ili_predpolagayushchie_perekhod_ na_msfo/https:/www.businessinfo.cz/ru/upravlenie-kompaniej/vedenie-bychgalterskogo-uceta.html (in Russian; accessed 13 June 2020 ).

${ }^{3}$ Foundation for the Development of Accounting "National Non-Government Standard-Setter 'Accounting Methodological Centre”. URL: http:// bmcenter.ru/News/obsugdeniye_FS-OS (in Russian; accessed 14 January 2021).

${ }^{4}$ Ministry of Finance of the Russian Federation. URL: https://minfin.gov.ru/ru/perfomance/accounting/ development/project/ (in Russian; accessed 14 January 2021).

${ }^{5}$ Institute of Professional Accountants of Russia. URL: https://www.ipbr.org/en/ (accessed 14 January 2021).
} 
The Ministry of Finance of the Russian Federation is also an active developer of new standards. The approval of FAS 25/2018 "Lease Accounting" in autumn 2018 was a major achievement. This standard is fully based on the provisions of IFRS 16 "Leases". There had been no such standard in the RAS system before. It contains concepts that have not been previously applied in Russian accounting, such as the right to use an asset, the fair value of a leased object, the present value of future lease payments, the estimated liability connected with a leased object, the liquidation value of a leased object and a number of others.

\section{New employer requirements for graduates}

The new procedure for the development and approval of federal accounting standards began to be applied in practice in 2016-2018. At this time, employer requirements for accounting specialists also began to change. For example, the Mechel Group (one of the largest concerns in Russia, whose biggest portfolio asset is the Chelyabinsk Metallurgical Plant, http://www.mechel.ru/) formulated a number of requirements for accounting graduates, including the following competencies:

1) Knowledge, abilities and skills of applying current (not yet abrogated) accounting standards.

2) Understanding the principles and fundamentals of accounting according to IFRS.

3) Knowledge (at the level of understanding) of new federal accounting standards (or their draft versions).

These requirements are listed in a cooperation agreement between the company and South Ural State University (signed on December 17, 2017). In 2018-20, about 40\% of graduates of the university's Department of Accounting, Analysis and Audit who had such competencies were invited to work not only at Mechel but also in large audit companies (both Russian and international). Our analysis has shown that about $60-70 \%$ of them actively participate in the department's research work involving the development of new accounting standards in Russia and the application of IFRS principles. However, the current curriculum approved by the Ministry of Science and Education of Russia ${ }^{6}$ focuses only on existing Russian standards and does not provide for the formation of competences in IFRS and future accounting standards. Therefore, no methods have been developed for simultaneously teaching different accounting standards.

Thus, a peculiar feature of teaching during the active phase of the accounting reform in Russia (2019-2022) is that graduates are being simultaneously taught three different accounting systems: (1) the current Russian system, (2) the system patterned after international financial reporting standards that are used as a basis for the development of new Russian standards, and (3) the system based on the draft federal accounting standards, which will gradually come into force within the prescribed period. This problem is also relevant for many other countries of the post-Soviet space, in which national accounting is harmonized with international practices.

\section{Review of literature}

In recent years, many Russian scholars have studied different issues relating to the reform of national accounting: A.S. Bakaev [1; 2], V.G. Getman [3; 4], T.Y. Druzhilovskaya \& E.S. Druzhilovskaya [5-7], I.R. Sukharev [8; 9], L.I. Khoruzhiy [10], S.A. Kuzubov [11], K.O. Shayaxmetova \& A.S. Krikunov [12], L.Z. Shneidman [13], E.Y. Svyatkovskaya [14], etc. Unfortunately, as there are very few papers covering these issues in the English language, English-speaking readers are unable to keep track of accounting reform in Russia. The landmark work of R.W. McGee [15] is the best known, yet this book was published 10 years ago. Among recent works, the most comprehensive review of this reform is presented in a paper by N. Generalova, G. Soboleva, and N. Sokolova [16].

A review of approaches to teaching accountants at universities in developed countries leads to the conclusion that the main learning technology remains the case study, to which over $50 \%$ of articles in profile journals have been devoted over the past 10 years [17]. There is a great need for technological innovation (online assessment, online instructional resources, managerial accounting software, digital education tools, social media such as Facebook and Twitter, multiple software systems, tax software, Tableau, etc.), yet this process is not dynamic enough for the time being [17-19]. Research as a pedagogical technology is also used in preparing bachelor's students majoring in accounting. In particular, James H. Irving has noted that the use of primary source materials allows students to find and identify answers to a number of complex accounting questions, as well as developing oral and written communication skills, enhancing knowledge through teamwork, promoting the interaction of students in groups, and making them familiar with business-related applications of technologies [20].

At the same time, the system of accounting education in Russia has begun to change rapidly. One of the reasons is the influence of IFRS (Vysotskaya \& Prokofieva [21]). A recent study by T.T.Y. Chen that compared trends in accounting education in Russia, China and English-speaking countries concluded that innovative curricula and teaching methods should become a priority for former communist countries implementing accounting reform [22]. Consequently, when the Russian accounting reform enters its active phase, the problem of the development and introduction of such curricula and methods will become increasingly relevant. These curricula and teaching methods must take the transition to the new standards into account.

\footnotetext{
${ }^{6}$ Federal State Educational Standard of Higher Education. Bachelor's level. Economics. URL: http://fgosvo.ru/uploadfiles/fgosvob/380301.pdf (in Russian; accessed 12 December 2020).
} 
From our point of view, the development of James H. Irving's approach based on individual student research work would be promising in the present-day Russian context characterized by an abundance of primary sources and new accounting tasks.

\section{Methodology}

South Ural State University has developed a methodology for teaching bachelor's students the necessary competencies for managing accounting records in the new conditions. These conditions are characterized by the fact that, while enterprises are still performing accounting according to the previous standards, new accounting standards fully harmonized with the IFRS will have come into force by the time students complete their studies (or soon after their graduation). In addition, as the practice of Russian enterprises has shown, new standards will begin to be applied before the appointed date to allow greater flexibility in the introduction of new accounting regulations. In particular, many big companies have already started to apply FAS 25/2018 "Lease Accounting", although the starting date for its compulsory use is January 1, 2022.

The development of new approaches to teaching students in such conditions began with training seminars for lecturers from the Department of Accounting, Analysis and Audit. In 2016, South Ural State University began to cooperate with the Foundation "NSS 'AMC", with whom it signed an agreement in 2017. Lecturers take part in the Foundation's methodological activities by drafting FAS and accounting recommendations. An accounting analysis laboratory was jointly established by the University and the Foundation. The laboratory provides a platform for video conferences and webinars, as well as video broadcasts of meetings of the Foundation's methodological specialists, at which new draft accounting standards are discussed. The University participated in drafting the FAS "Inventories", "Intangible Assets", "Capital Investments", and "Receivables and Payables". This has allowed it to identify the most important novelties in the future standards and to include them in the educational process. However, the main task at this stage is for lecturers to understand the scope of the new standards in an interactive and high-quality manner and to develop the corresponding teaching and learning aids.

The preliminary work on training lecturers of the SUSU Department of Accounting, Analysis and Audit to teach students in the conditions of in-depth accounting reform has cast the foundations for the development and implementation of new teaching methods. These methods make it possible to teach students to work in the conditions of the transition to IFRS-compatible standards. The development of these methods has led to significant changes in the curricula of accounting courses. The methods are based on a new structure of professional competencies that are formed during the learning process. The new competency structure makes use of learning outcomes [24].

The methodology includes five interconnected components that correspond to the successive levels of mastery of a field of professional activity drawn from Bloom's taxonomy [23; 24]: knowledge, comprehension, application, analysis and synthesis. A higher level (grade) of mastery is formed by master's programmes.

The first level of the methodology is the formation of knowledge. A unique feature of the proposed methodology is that it clearly identifies the topics that require coverage in major courses with regard to all three accounting systems:

1) The accounting system currently in force in Russia and set out in the Russian Accounting Standards (RAS).

2) The international accounting system set out in the International Financial Reporting Standards (IFRS), which serves as a methodological framework for the reform of accounting in Russia.

3) The accounting system contained in draft Federal Accounting Standards (FAS).

Lecture materials cover accounting principles, concepts and regulations from all three systems of standards. Students study the material independently for the most part. In each practical class, the lecturer explains the most difficult aspects of the topic, gives examples and then assigns students exercises to consolidate the studied material. Thus, the methodology forms knowledge through the use of traditional teaching methods.

Assimilating this vast material at the level of comprehension requires the use of active teaching methods. The department recommends that such teaching methods be supplemented with in-class discussions of the novelties of future standards with regard to the studied questions and topics. When preparing to discuss a specific topic, students study materials from the website of the Foundation "NSS 'AMC"' containing texts of draft and adopted standards. In these texts, they have to identify principles, definitions of concepts, and basic accounting regulations. At mini-conferences, students explain the new material, discuss the mistakes made in the presentations, and express their opinions.

Mastering accounting at the level of application takes place in two stages. The first stage involves studying a case from each topic. Specialists from the department's partner companies (industrial enterprises and audit companies) participate in this process. The topic being studied is connected to real situations, prepared in advance by company specialists and harmonized with the department. As a rule, this is a rather difficult assignment for students that requires not only comprehension but also calculations. A course consisting of 4 credits usually includes 4-6 topics exemplified by practical situations. The second stage involves the solution of these problems and the assimilation of calculational skills.

Mastering accounting by bachelor's students at the level of analysis also takes place in two stages. During the first stage, the valuable methodological material accumulated by colleagues from the Foundation "NSS 'AMC"' is used extensively. The Foundation's website provides access 
to an archive of different versions of standards as well as comments submitted during the discussions of new draft standards. Each student is invited to choose one of the comments and give his/her own answer to the question of why the comment was not accepted.

The second stage of the formation of the ability to analyse subject matter is based on a totally new role and organisation of student research work during each semester under the guidance of a lecturer. Student research projects (SRPs) are considered as an interdisciplinary form of student individual work. All the topics of the SRPs are aimed at a profound study of draft FAS. Students work on project teams, which increases the effectiveness of learning. The main skill formed during the R\&D process is the ability to highlight key elements of an accounting standard and, on the basis of this analysis, make tables comparing the key provisions of the standards of the three accounting systems. We recommend using PricewaterhouseCoopers' document "Similarities and Differences: A Comparison of International Financial Reporting Standards with Russian Accounting Regulations" ${ }^{\text {" }}$ to learn how to highlight key elements and build a comparative table. In this case, the comparison covers not two but three accounting systems (therefore, the table contains 4 rather than 3 columns: topic (reflecting the key elements to be compared), RAS, IFRS, and draft FAS).

The R\&D gives rise to an obligatory progress report, which ends with a final comparative table and its interpretation. As a rule, students also willingly participate in the yearend academic conference (the number of participating students has more than doubled since 2016). Students also publish their research findings in articles (the share of such students is over $50-60 \%$ today in comparison to less than $15 \%$ in 2016).

Accounting is mastered at the level of synthesis through the student final project that is an analogue of Capstone and other practice-oriented projects used in different countries. The department has elaborated new requirements for final research projects. The uniqueness of this level of the methodology is that it highlights two aspects of this skill - methodical and organisational. The need for such an approach is explained by the fact that future specialists should be able not only to make calculations using the methods outlined in the new draft accounting standards but also to organise the transition from the old to the new standards. The latter may be called the skill of developing a business process for the transition from existing to new accounting standards. A peculiar feature of this business process is that it is implemented in the conditions of the ongoing management of accounting records at the enterprise, which cannot be stopped even temporarily.

In the next section, we will consider in more detail some underlying aspects of the methodology.

\section{The attraction of specialists from the department's partner companies}

The attraction of specialists from the department's partner companies is one of the intensive teaching methods used at SUSU. Since the 2017-2018 academic year, specialists from partner companies have taken an active part in teaching at the department. At the beginning of the semester, a schedule of classes by specialists is drawn up. The main criterion for the selection of topics is the need to explain the provisions of the new accounting standards that are difficult to understand and apply. These provisions are generally lacking in the current standards. For example, specialists of the Avuar Group have held practical classes with $3^{\text {rd }}$ and $4^{\text {th }}$-year bachelor's students on the following topics: professional judgments by accountants during the transition to new accounting standards, accounting for estimated liabilities, and lease accounting. Specialists of the Mechel Group have held master and practical classes on the following topics: accounting for reserves and their reflection in accounting policy, accounting under IFRS in a public company (issues of organising accounting and disclosure), and automating accounting in the conditions of continuously changing accounting standards.

\section{Student research work}

By the decision of the university academic council, individual semester-long research work under the guidance of a lecturer has been introduced into the curriculum of bachelor's students in economics (semesters 4-6, 324 hours of student independent work). The department provides a list of topics for student research work relating to specific aspects of the application of draft FAS. The student assignment includes the independent evaluation and commentary of draft FAS.

When performing the assignment, the student must compare the current accounting procedure with the procedure proposed in a draft FAS. In addition, a comparison is also made with the relevant IFRS procedure. Based on these comparisons, the student evaluates the degree of harmonization of accounting standards for individual objects and learns to work with the new standards. Another compulsory element of the assignment is to design a case that would reflect the realities of the business life of an organisation as required by each standard. The assignment ends with the development of recommendations on improving the text of the draft FAS in the aspects considered by the student.

Examples of topics for individual research assignments:

1) Accounting for estimated obligations for the dismantling and disposal of property and the environmental recovery of the land plot occupied by it that arise in a company in connection with its receipt of fixed assets.

\footnotetext{
${ }^{7}$ Similarities and differences: Comparison of International Financial Reporting Standards with Russian Accounting Regulations. URL: https://www. pwc.ru/ en/ifrs/publications/assets/rar-versus-ifrs-2015.pdf (in Russian; accessed 18 October 2020).
} 
2) Accounting for the revaluation and impairment of fixed assets.

3) Accounting for inventories during a significant reduction in the rate of operation in the reporting period as compared to the regular level.

4) Accounting for inventories in the case of purchases on deferred payment conditions for a period exceeding 12 months.

5) Accounting for the disposal of intangible assets at non-zero disposal value.

Thus, research work serves as the basis for the formation of a whole range of professional competencies related to the new standards. One of the basic skills to be mastered by the student is drawing up a comparative table of the provisions of RAS, IFRS and FAS (or their drafts, if the standard has not been approved by the Russian Ministry of Finance so far) as well as drawing conclusions about the similarities and differences of these accounting systems.

\section{Student final research project}

In 2017-2018, the Department of Accounting, Analysis and Audit changed the recommended structure of the bachelor's final research paper. The final research project must now include a section forecasting changes in the accounting procedures at the studied enterprise after the adoption of the FAS related to the topic of the paper. The student must assess the consequences of the change in the accounting procedures for the enterprise's financial statements and recommend changes to its accounting policy. In addition, the student can choose a topic related to the analysis of a specific draft FAS.

Here are some examples of topics of final research papers defended in 2018-2020: "Accounting and Audit of Investment Property According to IFRS Using the Russian Plan of Accounts", "Accounting and Analysis of the Property, Plant and Equipment of Ariant Agricultural Company LLC in the Conditions of Reforming Russian Accounting Standards", "Accounting for Deferred Taxes According to IFRS and RAS (Comparative Analysis)", "Harmonization of Property, Plant and Equipment Accounting Regulations in the Russian Federation with International Financial Reporting Standards", and "Accounting for Subsidies and Disclosure of Government Assistance in Financial Statements".

As an example, let us examine in greater detail a final research paper on the topic "Harmonization of Property, Plant and Equipment Accounting Regulations in the Russian Federation with International Financial Reporting Standards". The recommended scope of the paper is presented in Table 2.

Table 2. Recommended scope of the final research paper on the topic "Harmonization of Fixed Assets Accounting Regulations in the Russian Federation with International Financial Reporting Standards”

\begin{tabular}{|c|c|c|c|}
\hline $\begin{array}{l}\text { Section } \\
\text { number }\end{array}$ & $\begin{array}{l}\text { Section } \\
\text { name }\end{array}$ & $\begin{array}{l}\text { Subsection } \\
\text { number }\end{array}$ & $\begin{array}{l}\text { Subsection } \\
\text { name }\end{array}$ \\
\hline \multirow{3}{*}{1} & \multirow{3}{*}{$\begin{array}{l}\text { Genesis of account- } \\
\text { ing reform in the } \\
\text { Russian Federation }\end{array}$} & 1.1 & Premises for accounting reform in Russia \\
\hline & & 1.2 & Stages of the accounting reform \\
\hline & & 1.3 & $\begin{array}{l}\text { State-of-the-art procedure for the development and approval of } \\
\text { documents pertaining to accounting regulation }\end{array}$ \\
\hline \multirow{3}{*}{2} & \multirow{3}{*}{$\begin{array}{l}\text { Russian and interna- } \\
\text { tional property, plant } \\
\text { and equipment ac- } \\
\text { counting regulations }\end{array}$} & 2.1 & $\begin{array}{l}\text { Evolution of the Russian property, plant and equipment account- } \\
\text { ing standards: the harmonization with international financial } \\
\text { reporting standards }\end{array}$ \\
\hline & & 2.2 & $\begin{array}{l}\text { The need to reform existing property, plant and equipment ac- } \\
\text { counting procedures }\end{array}$ \\
\hline & & 2.3 & $\begin{array}{l}\text { Similarities and differences of the draft federal accounting stan- } \\
\text { dard "Property, Plant and Equipment" and IFRS (IAS) } 16 \text { "Proper- } \\
\text { ty, Plant and Equipment" }\end{array}$ \\
\hline \multirow{5}{*}{3} & \multirow{5}{*}{$\begin{array}{l}\text { Procedures for the } \\
\text { practical application } \\
\text { of the provisions } \\
\text { of the draft federal } \\
\text { accounting standard } \\
\text { "Property, Plant and } \\
\text { Equipment" }\end{array}$} & 3.1 & $\begin{array}{l}\text { Accounting for the initial recognition of property, plant and equip- } \\
\text { ment }\end{array}$ \\
\hline & & 3.2 & Accounting for the depreciation of property, plant and equipment \\
\hline & & 3.3 & Accounting for revaluations of property, plant and equipment \\
\hline & & 3.4 & Accounting for the impairment of property, plant and equipment \\
\hline & & 3.5 & Accounting for the disposal of property, plant and equipment \\
\hline
\end{tabular}


The preparation of the bachelor's final research project completes the formation of professional competencies relating to the new standards. The student profoundly assimilates an accounting topic by describing the current accounting procedure, the main provisions of the new standards, and the organisation of the process of the transition to new standards at a particular enterprise. The effectiveness of this stage of bachelor's education has been highly evaluated by specialists of partner enterprises that took part in the work of the project defence committee. Almost one third of graduates in 2018-2020 received job offers from companies. Given that another quarter of the students were invited even earlier to work in major regional companies, this is a very high index of graduate employment in highly prestigious companies.

\section{Results}

The described methods have already been applied for 10 semesters, starting from autumn 2016. The obtained re- sults can be systematized in three areas relating to the main stakeholders of the new educational process:

1) The activity and interest in the educational process among students as the main targets of the new methods:

2) The activity and interest in work based on the new methods among lecturers as the main actors of the educational process.

The activity and interest in programme graduates of employers as the main beneficiaries of the new teaching methods.

The main quantifiable results are presented in Tables 3 and 4. Since the introduction of the new intensive methods for teaching bachelor's students, the following aspects have changed significantly: students' research activity, participation in the implementation of real projects, readiness to undertake internships and part-time work at the department's partner enterprises, attitude to choosing places of internship, and attitude to choosing the topic of the final research project.

Table 3. Relative* changes in indicators characterizing the results of the introduction of intensive teaching methods for bachelor's students in accounting at SUSU: the achievements of students

\begin{tabular}{|c|c|c|c|c|}
\hline Indicator & $\begin{array}{l}2016-2017 \\
\text { academic } \\
\text { year }\end{array}$ & $\begin{array}{l}2017-2018 \\
\text { academic } \\
\text { year }\end{array}$ & $\begin{array}{l}2018-2019 \\
\text { academic } \\
\text { year }\end{array}$ & $\begin{array}{l}2019-2020 \\
\text { academic } \\
\text { year }\end{array}$ \\
\hline $\begin{array}{l}\text { Percent share of students participating in research } \\
\text { project teams }\end{array}$ & 20 & 35 & 60 & 65 \\
\hline $\begin{array}{l}\text { Percent share of students participating in academic } \\
\text { conferences }\end{array}$ & 15 & 15 & 40 & 50 \\
\hline $\begin{array}{l}\text { Percent share of students publishing their research } \\
\text { results }\end{array}$ & 10 & 22 & 30 & 50 \\
\hline
\end{tabular}

* Absolute values are not representative due to the different numbers of $3^{\text {rd }}$ and $4^{\text {th }}$-year students in the bachelor's accounting study programme.

Table 4. Changes in indicators characterizing the results of the introduction of intensive teaching methods for bachelor's students in accounting at SUSU: the achievements of lecturers

$\begin{array}{lllll} & 2016-2017 & 2017-2018 & 2018-2019 & 2019-2020 \\ \text { Indicator } & \text { academic } & \text { academic } & \text { academic } & \text { academic } \\ & \text { year } & \text { year } & \text { year } & \text { year }\end{array}$

Number of research articles published by the depart-

ment's lecturers on subjects relating to the accounting $\quad 1$

reform in Russia*

Number of lecturers participating in the activities of the methodological specialists of the Foundation "NSS 1 'AMC"'

* Only publications in journals indexed by the Russian RSCI citation base are taken into account. 
From the $3^{\text {rd }}$ year on, students become involved in research work in areas relating to the development and implementation of new national accounting standards. The share of $3^{\text {rd }}$ and $4^{\text {th }}$-year students working on project research teams amounted to $20 \%$ during the 2017-2018 academic year, $35 \%$ in $2018-2019$, and about $60 \%$ in 2019-2020. This figure seems to be close to the limit, since other students choose other areas of research (analysis, management accounting, internal control). These students were guided by lecturers who participated in the development of the new standards. The share of participants in academic conferences at SUSU and other universities who make reports on topics relating to the accounting reform also shows an upward trend. During the 2020-2021 academic year, this figure amounted to about $40 \%$ of all $3^{\text {rd }}$ and $4^{\text {th }}$-year students. Finally, the number of student publications on these topics is also growing: during the current academic year, 10-12 articles should appear. One also notes a growing number of participants and winners of all-Russian and international academic competitions, including competitions held by Big Four companies.

The lecturers' activities and academic interests include designing research and practical seminars covering the relevant accounting reform issues for other lecturers and chief accountants, making comments and proposals on drafting federal accounting standards, publishing research articles describing accounting procedures relating to the new federal standards, and participating in the activities of the methodological specialists of the AMC Foundation and other initiatives relating to the development of this focus area of the department. All the indicators show an upward trend (Table 4). Since the methodology was introduced, proposals have been developed and submitted for the following draft FAS: "Inventories", "Intangible Assets", and "Receivables and Payables". It is planned to increase the number of members in the Association of the AMC Foundation to 6 people, who will become active participants in the accounting reform process.

The most important achievement of department lecturers was winning a grant of the Vladimir Potanin Foundation ${ }^{8}$ for the development of the new master's course "Accounting and Auditing According to IFRS Using the Russian Plan of Accounts" in 2018-2019. The foundation's educational activities cover many different areas; they have the common goal of changing the educational environment, supporting the values of knowledge, professionalism, creativity and volunteering, and developing and diffusing new educational practices. Department staff is currently working on the development of the course. To this end, a textbook and software for innovative teaching methods have been created (December 2019).

Employers' activities and interests are conditioned by the need for highly qualified personnel. A shortage of special- ists in the field of accounting and auditing has emerged over the last 2-3 years under the influence of several objective and subjective factors. Some trends and figures in this area have been highlighted at conferences (in particular, at the conference of the Russian Union of Auditors - Russia's largest self-regulating organisation of auditors - entitled "On the role of auditing and economic development in Russia and the Russian Union of Auditors in the consolidation of the auditing community to increase the prestige of the auditor's profession at the Russian and international levels") and in the business press. ${ }^{9}$ However, the employers' interests are conditioned less by the shortage of specialists than by the need for personnel proficient in the new accounting methods. For example, in 2017 Mechel PJSC signed a cooperation agreement with SUSU for preparing economists. The company introduces new accounting methods before their official entry into force. The recommendations given by the specialists of the company's accounting and reporting department are taken into account when developing the curricula of bachelor's programmes. During the 2019-2020 academic year, 9 seminars and workshops were held for bachelors. 10 graduates were recruited to work for the company on the basis of their final papers in 2020; 7 of them are active participants in research work on accounting reform in Russia. Currently, 16 bachelors are working in the company on a part-time basis as well as participating in on-the-job and pre-graduation internships in the company's economic and accounting departments. The results of the joint project have been highly assessed by the management of Mechel PJSC; it is planned to expand the project to include accounting automation based on the new methodology.

\section{Discussion, limitations, and further research}

When we started working on this project, we realized that the need for intensive training methods will exist only so long as the accounting reform is underway. However, the government is constantly expanding the list of standards to be harmonized with IFRS. Therefore, our experience should be in demand for at least the next decade.

The methodology was developed with the help of two key resources of the SUSU Department of Accounting, Analysis and Audit. First of all, it is the only university department in the country that is a co-developer of new national accounting standards. Several lecturers serve as methodological specialists for the AMC Foundation. Secondly, there are many large industrial enterprises and audit companies in the Urals with which the university has partnership agreements.

A lack of such resources may seem to be a serious limitation to the use of our methodology. However, 4 or 5 years

\footnotetext{
${ }^{8}$ Vladimir Potanin Foundation. URL: https://www.fondpotanin.ru/ competitions/projects/ (in Russian; accessed 14 January 2021).

${ }^{9}$ Prosvirina, I.I. On the verge of extinction: Will the professions "accountant" and "economist" disappear? URL: https://chel.dk.ru/news/prezhniemetody-uderzhaniya-i-motivatsii-spetsialistov-ne-rabotayut-a-novye-ne-sozdany-237116304 (in Russian; accessed 14 January 2021 ).
} 
ago, our department did not have such opportunities, either. We decided to try to participate in the public discussion of draft FAS via the website of the AMC Foundation. Any interested person can do so, too. This helped us to sign a cooperation agreement and arrange joint work. In recent years, the search for partner enterprises has ceased to be a problem due to the shortage of specialists in the field of accounting. Enterprises facing the challenge of switching to new accounting methods have begun to cooperate actively with universities. Thus, most Russian universities can copy our experience.

We shall continue our department's work on the further development and diffusion of our methodology through the creation of new teaching and learning aids. We have already gathered a lot of materials for this in the form of assignments, practical tasks and cases prepared by department lecturers, the data of our published studies dealing with accounting reform in Russia, and the developments of the department's partners - specialists from enterprises and audit companies. These materials are currently being systematized and prepared for publication.

Our plans for developing intensive teaching methods include an opinion survey of department students and graduates who have been or are being taught with the new methods, as well as employers. To date, the total number of potential participants in the survey of students and graduates attains 350 people. Such a survey will allow us to obtain valuable comments and identify positive aspects of the methodology along with representative data on the necessary changes and directions for their refinement.

\section{Conclusion}

The current in-depth accounting reform in Russia, as well as the results of a study conducted by T.T.Y. Chen (Chen, 2015), showed the necessity of developing new approaches and introducing innovative methods for teaching bachelor's students in the field of accounting. When we started this project, we did not expect it to lead to the revision of virtually all elements of the educational process. The keystone of the new methodology is the employers' need for specialists who are able to work in the conditions of the constant introduction of new accounting standards. The main task of the university was to form knowledge with an eye to the future: students must be familiar with standards that have not yet come into effect (at least, with their basic concepts and approaches to accounting and their differences from existing standards).

The search for a teaching methodology led us to the learning outcomes approach, which fully meets employers' needs. In view of the requirements laid down by the department's partner companies, students assimilate professional activities at the levels of knowledge, comprehension, application, analysis and synthesis. The methodology developed in 2016-2018 contains teaching methods for each of these levels. In particular, the methodology includes the following innovations:

1) Classes taught by specialists from partner companies.
2) Use of the database of the AMC Foundation, which contains comprehensive information about the process of developing new standards.

3) Introduction of individual student research work under the guidance of department lecturers who are co-developers of the new accounting standards and with the use of project-based teaching.

4) New requirements for the final project that allow students to synthesize the skills acquired at previous levels into a unified system by developing a project for a specific enterprise (as a rule, the project involves methodological and organisational preparation for the transition to one of the new accounting standards).

5) Greater satisfaction of graduates with the results of their studies, as shown by (a) the increasing quality of student performance in the $3^{\text {rd }}$ and $4^{\text {th }}$ years: the share of students with good and excellent grades increased from $55 \%$ in 2018 to $71 \%$ in 2020 , (b) the increasing number of $3^{\text {rd }}$ and $4^{\text {th }}$-year students wishing to participate in internships with partner companies: the percentage of students combining studies and internships increased from 10\% in 2018 to $35 \%$ in 2020 , (c) the high proportion of students seeking to find employment in partner companies after graduation (at least 75\%), and (d) the quick career growth of graduates after employment with no dismissals during the period of observation from 2018 to 2020 .

There is no doubt that these indicators result from the introduction of the new methodology, as other factors remained unchanged during this period. In particular, the same educational standards (Federal State Educational Standard of Higher Education 3+), curricula and academic course programmes have remained in force since 2015. The teaching staff of the department has not changed, either.

The improvement in results became particularly visible in summer 2018. As we highlighted in departmental reports, student research activity (participation in conferences and publication of articles) increased by 2-3 times over 6 academic semesters, and many students became participants and winners of high-level academic competitions. Nevertheless, the main result is that $38 \%$ of our graduates have received job offers from big prestigious companies. Previously, employers of this type had usually required work experience, and our graduates often did not meet these requirements. Therefore, we link the improvement of our educational process to the new methodology of teaching bachelor's students in the field of accounting described in this article.

\section{References}

1. Bakaev A.S. On some questions of new chart of accounts for bookkeeping development. Audit = The Audit Magazine. 2015;(3):21-23. (In Russ.). 
2. Bakaev A.S. Does Russian accounting system have prospectives? Audit = The Audit Magazine. 2015;(4):2-4. (In Russ.).

3. Getman V.G. Urgent issues of further development of accounting in commercial entities. Uchet. Analiz. Audit = Accounting. Analysis. Audit. 2016;(1):99-103. (In Russ.).

4. Getman V.G. On the issues of further development of accounting in commercial organizations. Upravlencheskii uchet $=$ The Management Accounting Journal. 2016;(1):73-78. (In Russ.).

5. Druzhilovskaya T.Yu., Druzhilovskaya E.S. New accounting: Draft new federal standards. Bukhgalterskii uchet $v$ byudzhetnykh $i$ nekommercheskikh organizatsiyakh = Accounting in Budgetary and Non-Profit Organizations. 2017;(5):29. (In Russ.).

6. Druzhilovskaya T.Yu., Druzhilovskaya E.S. The reform of the Russian accounting of public sector organizations in the transition to new accounting standards. Vestnik Nizhegorodskogo universiteta im. N.I. Lobachevskogo. Seriya: Sotsial'nye nauki = Vestnik of Lobachevsky State University of Nizhni Novgorod. Series: Social Sciences. 2015;(4):18-26. (In Russ.).

7. Druzhilovskaya T.Yu., Druzhilovskaya, E.S. Reforming normative regulation system of Russian accounting under IFRS. Mezhdunarodnyi bukhgalterskii uchet = International Accounting. 2014;(19):2-18. (In Russ.).

8. Sukharev I.R. The importance of introducing IFRS in Russia. Bukhgalterskii uchet. 2012;(3):7-13. (In Russ.).

9. Sukharev I.R. New accounting standards: A look into the future. Nalogovaya politika i praktika. 2013;(1):15-19. (In Russ.).

10. Khoruzhiy L.I. Analysis of new laws on accounting and taxation in the Russian Federation. Vestnik IPB (Vestnik professional'nykh bukhgalterov) $=$ Bulletin for Professional Accountants. 2017;(5):17-22. (In Russ.).

11. Kuzubov S.A. Foresight of the financial professions: Accountant and auditor (Roundtable results). Korporativnye finansy = Journal of Corporate Finance Research. 2016;10(4):7-8. (In Russ.). https://doi. org/10.17323/j.jcfr.2073-0438.10.4.2016.7-8

12. Shayakhmetova K.O., Krikunov A.S. Harmonization of economic dimensions as a mechanism for ensuring the comparability of investment objects in the context of globalization. Korporativnye finansy = Journal of Corporate Finance Research. 2017;11(2):46-54. (In Russ.). https://doi.org/10.17323/j.jcfr.20730438.11.2.2017.46-54

13. Shneidman L.Z. Transition to IFRS: Status and next steps. Finansy = Finance. 2013;(1):6-10. (In Russ.).
14. Svyatkovskaya E.Yu. Accounting and assessment of the risk of material misstatement of accounting (financial) statements in a control-oriented accounting system. Korporativnye finansy = Journal of Corporate Finance Research. 2016;10(2):5-26. (In Russ.). https://doi.org/10.17323/j.jcfr.20730438.10.2.2016.5-26

15. McGee R.W., ed. Accounting reform in transition and developing economies. New York: Springer US; 2009. $521 \mathrm{p}$.

16. Generalova N., Soboleva G., Sokolova N. IFRSRussian experience: Realities and challenges. In: Innovation vision 2020: From regional development sustainability to global economic growth. Proc. $25^{\text {th }}$ International Business Information Management Association conf. (Amsterdam, May 7-8, 2015). King of Prussia, PA: IBIMA; 2015:601-608.

17. Campbell R., Owens-Jackson L., Theuri P. Literature review of technology-related research in accounting education: 2010-2020. SSRN Electronic Journal. 2021. http://dx.doi.org/10.2139/ssrn.3802292

18. Hoelscher J., Mortimer A. Using Tableau to visualize data and drive decision-making. Journal of Accounting Education. 2018;44:49-59. https://doi. org/10.1016/j.jaccedu.2018.05.002

19. Alshurafat H., Beattie C., Jones G., Sands J. Perceptions of the usefulness of various teaching methods in forensic accounting education. Accounting Education. 2020;29(2):177-204. https:// doi.org/10.1080/09639284.2020.1719425

20. Irving J. Integrating research into an undergraduate accounting course. Issues in Accounting Education. 2011;26(2):287-303. https://doi.org/10.2308/iace-10016

21. Vysotskaya A., Prokofieva M. The difficulties of teaching IFRS in Russia. Issues in Accounting Education. 2013;28(2):309-319. https://doi. org/10.2308/iace-50363

22. Chen T.T.Y. Is reform in accounting education needed in China and Russia: A literature review. Australasian Accounting, Business and Finance Journal. 2015;9(3):72-83. http://dx.doi.org/10.14453/ aabfj.v9i3.6

23. Anderson L., Krathwohl D., eds. A taxonomy for learning, teaching, and assessing: A revision of Bloom's taxonomy of educational objectives. New York: Longman; 2001. 333 p. URL: https://www. uky.edu/ rsand1/china2018/texts/AndersonKrathwohl\%20-\%20A\%20taxonomy\%20for\%20 learning\%20teaching\%20and\%20assessing.pdf

24. Using learning outcomes. European Qualifications Framework Series: Note 4. Luxembourg: Publications Office of the European Union; 2011. 52 p. URL: https://www.cedefop.europa.eu/files/Using_learning_ outcomes.pdf 